\title{
Mao Zedong kot poslednji konfucijanski vladar? Moralno-didaktični vidik »konfucijanske« umetnosti
}

Ključne besede: konfucijanska umetnost, moralno-didaktični vidik, narativno slikarstvo, cesar Taizong, cesar Gaozong, Mao Zedong

DOI: $10.4312 /$ ars.10.1.133-161

\section{Uvod}

Umetnost izvira iz specifično kulturnih in družbeno-političnih sistemov ter jo je treba kot tako interpretirati v odnosu do kulturnih implikacij, saj predstavlja vizualno reprezentacijo kulture. Individualni kulturni koncepti so bolj ali manj latentno implicirani v vizualni sistem slikovnega gradiva, ki ga spretno upodobi umetnik. Vizualni jezik ni nikoli tako enostaven, neposreden in izrazen kot ustni jezik ter redko eksplicitno izraža pomen kakršnihkoli filozofskih idej in ideoloških pojmov, po drugi strani pa funkcionira kot vizualni medij, ki poskuša dešifrirati zamegljeno, prikrito ali težko razumljivo povezavo med določenim vizualnim vzorcem in njegovim filozofskim izvorom. Filozofija in umetnost sta tako tesno prepleteni področji, znotraj katerih se posamezni filozofski koncepti manifestirajo v specifičnih oblikah vizualne umetnosti.

Specifične značilnosti kitajske umetnosti, znotraj katere je že vse od dinastije Tang 唐 (618-907) dominantno vlogo prevzelo slikarstvo, so še toliko bolj inherentno povezane s kulturno, ideološko in filozofsko podlago takratnega družbeno-političnega sistema. Brez upoštevanja posamičnih filozofskih idej vsakršna interpretacija individualnih značilnosti kitajskega vizualnega jezika ostaja fragmentarna, odgovori na vprašanja o izvoru, pomenu, funkciji ter uporabi črnila in vode na svili ali riževem papirju v obliki vodoravnih ali navpičnih zvitkov ali drugih oblikah kitajskega slikarstva pa zgolj elementarni poskusi interpretacij, ki ne podajajo poglobljene in celostne analize v zapleteni mreži kulturnih implikacij.

Konfucianizem, daoizem in budizem predstavljajo tri glavne stebre tradicionalne kitajske družbe in so s svojimi idejnimi nazori pomembno vplivali na specifičen razvoj kitajskega slikarstva. Medtem ko večina sodobnih učenjakov in umetnostnih zgodovinarjev priznava pomembno vlogo daoizma, ki jo je igral pri razvoju kitajskega krajinskega slikarstva, in ugotavlja razvoj specifične budistične umetnosti v kitajski 
preobleki, se vpliv konfucijanske ideologije kot idejnega sistema, ki je bistveno vplival (in ima še vedno pomembno vlogo) na razvoj družbenega sistema Kitajske, odraža predvsem $\mathrm{v}$ moralnih in didaktičnih premisah narativnih ilustracij. Te so služile kot odličen medij za izražanje, širitev in potrjevanje kulturnih vrednot, ki jih je promoviral konfucijanski kanon. Vladarji, uradniki, učenjaki in drugi so s pomočjo vizualnega medija v obliki narativnih ilustracij poskušali širiti svoje ideje o cesarski suverenosti, politični legitimaciji, nebeškem mandatu, družbeni harmoniji in hierarhiji ter ne nazadnje o osebni moralni in didaktični vzgoji. Pri tem so posegali po številnih temah in zgodbah, ki so jih izbrali iz klasičnega korpusa konfucijanskih del, zgodovinskih zapisov, literature in tudi sodobnih dogodkov. Posamezna dela so bila namenjena različnim družbenim slojem, ki so vključevali tako uradnike, ministre in učenjake kot tudi same cesarje in njihove mladoletne prestolonaslednike, velik korpus pa je bil namenjen tudi ženskam, ki so nastopile službo dvorjanke ali so svojo pokornost izražale v odnosu do moža znotraj družinskih vezi. Teme, ki so jih upodabljali, so bile povezane $\mathrm{z}$ osrednjimi konfucijanskimi vrlinami, predvsem $\mathrm{s}$ spoštovanjem nadrejenega, pa naj bo to v smislu hierarhičnih odnosov med vladarjem in podložnikom, očetom in sinom, možem in ženo ter starejšim in mlajšim bratom. Po drugi strani pa so s posameznimi vizualnimi primeri preteklih vzornih vladarjev, ki so jih večkrat opremili z moralnimi teksti, opozarjali na vladarjeve dolžnosti ter njegovo moralno obveznost do podrejenih in celotnega družbenega sistema.

$\mathrm{V}$ pričujočem prispevku se bomo ukvarjali predvsem $\mathrm{z}$ vladajočo in izobraženo elito, ki je s pomočjo narativnih ilustracij izražala posamezne konfucijanske vrednote in s tem utrjevala politično legitimnost. Na primeru posameznih vladarjev bomo $s$ pomočjo vizualnega medija poskušali prikazati uporabo koncepta »konfucijanskega idealnega vladarja «, kot ga razkrivajo posamezni primeri narativnih ilustracij. Pri tem se bomo osredotočili predvsem na dva vladarja: prvega cesarja dinastije Tang Taizonga 太宗 (589-649), ki je s strogo politiko omogočil tehnološki in umetniški dvig Kitajske, ter desetega cesarja dinastije Song 宋 (960-1279) oziroma ustanovitelja dinastije Južni Song 南宋 (1127-1279) Song Gaozonga 宋高宗 (1107-1187). Oba vladarja sta s pomočjo narativnih zgodb o konfucijanski morali, idealih vladanja in družbeni harmoniji utrjevala svoje politično udejstvovanje in pravico do nebeškega mandata ter poskušala prikazati svojo predanost in zavezanost konfucijanskim načelom vladarjeve suverenosti. Hkrati sta na ta način poskušala dvigniti moralo uradnikom in ministrom ter jih nagrajevala za najzaslužnejša dejanja. Tovrstni poskusi utrjevanja lastne moralnosti $\mathrm{v}$ smislu idealnega vladarja po konfucijanskih načelih so se nadaljevali tudi v zadnjih dveh dinastijah. Še posebej impozantna cesarja zadnje dinastije Qing 清 (1644-1911) Kangxi 康熙 (1653-1722) in Qianlong 乾隆 (1711-1799) sta na ta način sofisticirano utrjevala avtoriteto Mandžurcev nad kitajskim prebivalstvom ter se 
prikazovala kot naslednika konfucijanskih vladarjev, ki posedujeta vsa osnovna načela idealnega vladarja.

Podobne težnje - čeravno zavite v komunistične ideologije 20. stoletja - bi lahko zaznali tudi v dejanjih in obnašanju velikega vodje komunistične Kitajske Mao Zedonga 毛澤東 (1893-1976). V času velike kulturne revolucije (1966-1976) je svoje moderne komunistične ideje s pomočjo didaktičnih narativnih ilustracij v obliki propagandnih plakatov spretno širil med sloje delavcev in kmetov. S tem ni le »moraliziral« in izobraževal širših krogov družbenih slojev, temveč je tudi utrjeval lastno avtoriteto. Zavito v simbolne ovoje novih ideologij in umetniških zvrsti je s pomočjo modela »konfucijanskega idealnega vladarja « legitimiral svojo politično oblast na podoben način, kot je mogoče opaziti pri številnih preteklih vladarjih.

$\mathrm{V}$ zadnjem delu prispevka bomo tako poskušali interpretirati Maove didaktične in moralne metode, ki jih je spretno udejanjil na propagandnih plakatih. Čeravno je enega izmed največjih napadov na konfucijansko ideologijo mogoče zaznati prav v Maovi zadnji kampanji proti konfucianizmu v letih 1974-1975, bi številne Maove podobe in druge družbeno angažirane prizore na propagandnih plakatih lahko interpretirali kot modificirano in moderno verzijo tradicionalnih konfucijanskih načel, prepredenih z modernimi formami vizualne umetnosti. Ali bi torej lahko Mao Zedonga označili kot zadnjega »konfucijanskega idealnega vladarja «, ki je v simbolnih preoblekah modernih tendenc utrjeval svoj nebeški mandat, bo osrednje vprašanje zadnjega dela pričujočega prispevka.

\section{Moralno-didaktična konotacija $v$ narativnem slikarstvu}

Pomembnost vizualnih podob je razvidna iz izjave, ki jo je na pragu 4. stoletja podal sloviti kitajski kaligraf in literarni kritik Lu Ji 陸機 (261-303): »Za širše poznavanje stvari ni nič pomembnejšega od besed, za ohranjanje njihove podobe pa ni nič boljšega od slikarstva« (Zhang, 1963, 2). Xie He 謝赫 (aktiven v 5. stoletju), ki je v slikarstvu zasnoval slavno teorijo šestih načel, je dobro stoletje kasneje v uvodu svoje knjige Guhua pinlu 古畫品錄 (Zapisi o starodavnih slikarjih) slikarstvu pripisal didaktično vlogo: »Nobena slika ne pojasnjuje spodbud ali svaril oziroma prikazuje vzpone in padce, a z odprtjem slike kot v ogledalu opazujemo tisoč let samote in tišine" (Xie, 1954). Tovrstno dojemanje slikarstva kot medija $\mathrm{z}$ moralno-didaktično funkcijo je posledica konfucijanske ideologije in zagovornikov starodavnega učitelja Konfucija (551-479 pr. n. št.), saj naj bi zgodovinski dogodki, seveda v pravilni interpretaciji, utelešali moralne nauke, upodabljanje vzornih posameznikov pa naj bi bilo navdih za primerno obnašanje posameznika. Pretekli vzori naj bi tako služili stabilizaciji 
družbenega reda, s tem pa je preteklost dobila vlogo učitelja sedanjosti. Seveda je bilo to jasno povezano s sposobnostjo posameznikov, da so znali naslikano podobo identificirati in jo interpretirati v okviru prikazanih etično-moralnih norm.

Že samega Konfucija je obisk templja prednikov dinastije Zhou (1046-256 pr. n. št.), katerega stene so krasili portreti preteklih »zaslužnih in pokvarjenih « mož in žena, spodbudil k razmišljanju o preteklih lekcijah. Ko je strmel v podobo vojvoda Zhou 周公, ki je v času avdience pri uradnikih dinastije Zhou nosil mladega kralja Cheng 周成王 (1055-1021 pr. n. št.), je izjavil, da prizor uteleša vrlino, ki je dinastiji Zhou omogočila preživetje in obstoj več sto let (Murray, 2007, 27). Konfucij ter njegov sistem družbene etike in morale za potrebe harmonije in sožitja v takrat izredno burnem obdobju je tako vidno vplival tudi na kasnejši razvoj slikarstva, predvsem t. i. narativnih ilustracij. $S$ pomočjo didaktičnih vsebin tovrstnih upodobitev so posameznikom na vizualen način sporočali pravilen način obnašanja oziroma izvajanje "pravilnih « obredov $\mathrm{v}$ smislu petih glavnih konfucijanskih vrlin: ren 仁 (sočlovečnost), yi 義 (pravičnost), zhong 忠 (lojalnost), shu 恕 (prizanesljivost) in $z h i$ 知 (znanje).

Poleg tega je v Konfucijevi hierarhično urejeni družbi eden izmed najosnovnejših družbeno etičnih konceptov odnos med posameznimi predstavniki družbe, pri čemer Konfucij nazorno definira pet vrst medčloveških odnosov: odnos med vladarjem in podložnikom, očetom in sinom, možem in ženo, starejšim in mlajšim bratom ter odnos med prijateljema. Pri vseh teh odnosih (izjema je odnos med prijateljema) je osnovna vrlina xiao 孝 - spoštovanje in poslušnost podrejenega v odnosu do nadrejenega. T. i. koncept xiao 孝 je pridobil primarno vlogo v razvoju človekove morale, $\mathrm{v}$ času dinastije Han (106 pr. n. št.-220 n. št.) pa mu je bila pridana še družbena konotacija. Številni dokumenti xiao prikazujejo kot vir vseh ostalih vrlin, ki usmerja posameznike $\mathrm{k}$ doseganju najvišjega cilja izražanja spoštovanja, in sicer ne le v odnosu do vladarja, temveč celo v odnosu do neba (Wu, 1989, 180). Poleg tega je v času dinastije Han vodilni konfucijanski učenjak Dong Zhongshu 董仲舒 (179-104 pr. n. št.), reformator izvornega Konfucijevega nauka v državno ideologijo, ${ }^{1}$ izmed petih odnosov izbral tri najpomembnejše ter jih interpretiral $\mathrm{v}$ odnosu do kozmičnih načel in teorije yin yang 陰陽. Ti trije odnosi, ki jih je poimenoval Sangang 三綱 (tri vezi) (odnos med vladarjem in podanikom, med očetom in sinom ter med možem in ženo), so $\mathrm{v}$ konfucijanski državni ideologiji dinastije Han sestavljali osnovno mrežo družbenih odnosov. Po mnenju Dong Zhongshuja in drugih konfucijancev iz časa dinastije Han naj bi ti trije odnosi izhajali iz kozmoloških načel in ustrezali nasprotnima poloma sil yin in yang (Wu, 1989, 169-170), pri čemer vladar, oče in mož ustrezajo sili yang, podložnik, sin in žena pa sili yin. Tovrstna interpretacija se jasno odraža v številnih poslikavah dinastije Han, kjer se v odnosu vladar - podložnik odraža pomembnost

1 Več o njem in njegovi reformi Konfucijevega nauka glej Rošker, 2010. 
lojalnosti, v odnosu oče - sin spoštovanje in vzorno vedenje sina, v odnosu mož - žena pa absolutna pokorščina in lojalnost žene.

Poleg številnih portretov zaslužnih ministrov, uradnikov in generalov, ki so jih prikazovali na stenah palač in drugih državnih stavb ${ }^{2}$ ter na t. i. paravanih, je tovrstno didaktično tematiko mogoče opaziti tudi na oltarjih družine Wu 武, ki so bili v 2 . stoletju zgrajeni pred grobnicami uradnikov družine $\mathrm{Wu} v$ današnjem okraju Jiaxiang 嘉祥 v provinci Shandong 山東.
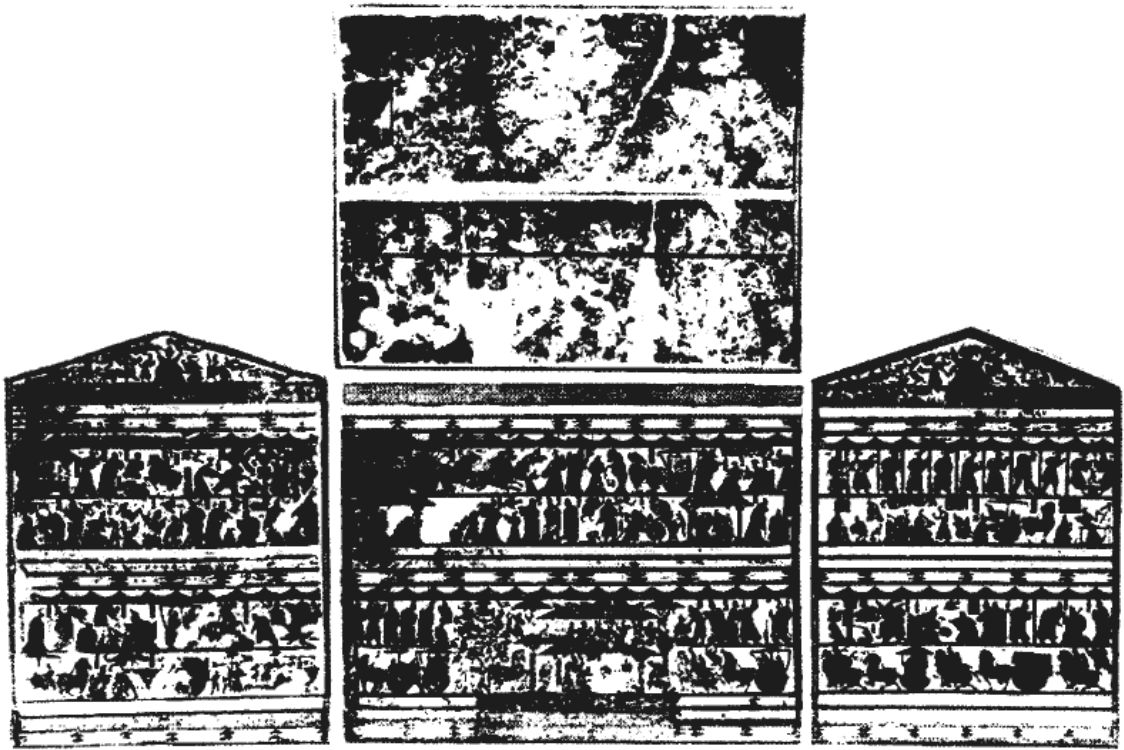

Slika 1: Rekonstrukcija oltarja Wuliang 武梁祠 s prikazom notranjih prizorov

(vir: Fairbank, 1941, slika 2).

Rezbarije na kamnitih ploščah jasno manifestirajo konfucijansko zasnovan ikonografski program. Na stenah je v osnovni liniji historiografije dinastije Han prikazana celotna človeška zgodovina, na zahodnem in vzhodnem zatrepu je prikazano nebeško kraljestvo zahodne matere (Xiwangmu 西王母) in vzhodnega očeta (Dongwanggong 東王公), strop pa je prekrit s serijo nepovezanih podob, ki jih napisi definirajo kot nebeška znamenja. Ta so se v skladu z Dong Zhongshujevo kozmologijo in zasnovo nebeškega mandata manifestirala $\mathrm{v}$ času moralnega ali nemoralnega obnašanja vladarja. Še posebej velja omeniti upodobitev 11 starodavnih legendarnih

2 Še posebej znane upodobitve vzornih posameznikov so bile naslikane na stenah spominskih dvoran, ki so bile zgrajene poleg cesarjevih palač. V dinastiji Zahodni Han (206 pr. n. št. -9 n. št.) je to opazno v t. i. »Paviljonu samoroga« v prestolnici Xi`an 西安, v dinastiji Vzhodni Han (25-220) pa na »Terasi oblakov«v prestolnici Luoyang 洛陽 (Murray, 2007, 27). Ti primeri so služili kot vzori tudi kasnejšim dinastijam. 
vladarjev, ki so jih idealizirali v brezčasne ikone človeške odličnosti. Sledi upodobitev narativnih prizorov, ki ilustrirajo najrazličnejše anekdote zaslužnih ministrov, mož, žen in njihovih otrok. Zanimiv je tudi način upodobitve, saj so starodavni vladarji prikazani kot individualni portreti, medtem ko so posamezni moralni junaki prikazani kot osrednja figura znotraj večje narativne kompozicije. Kot pravi Wu Hung (1989, 169), so starodavni modri vladarji utelešali najvišjo moralno odličnost človekovega obnašanja, medtem ko so zgodovinske osebe svoje izjemne vrline izražale le v odnosu do drugih ljudi ter v konkretni situaciji.

Pri upodobitvi zaslužnih oseb so tako vodilno vlogo odigrala etična načela medčloveških odnosov. Pri tem so se osredotočali predvsem na tri odnose, ki jih je izpostavil že Dong Zhongshu: odnos med vladarjem in podložnikom, očetom in sinom ter možem in ženo. Pri prikazovanju moralnega obnašanja žensk vse upodobitve sledijo didaktični knjigi z naslovom Lienü zhuan 列女傳 (Biografije zaslužnih žena), zbirki biografij zaslužnih žena iz starodavnih časov, ki jo je zbral in uredil Liu Xiang 劉向 (77-6 pr. n. št.). Zbirka je bila posebej zbrana in urejena za dvor kot nekakšen moralni učbenik za ženske, ki je temeljil na historičnih primerih moralnega obnašanja in drugih etičnih vrlin. ${ }^{3}$ Ena izmed upodobitev tako prikazuje vdovo, ki so ji dvorili številni pomembneži, vključno s kraljem. Kot užaloščena vdova in vdana pokojnemu možu je zavrnila vsa dvorjenja, pri tem pa si je brez zadržkov odrezala še nos, da bi se v bodoče izognila tovrstnemu nadlegovanju. Vdanost možu prikazuje tudi zgodba mačehe iz države Qi 齊, ki je zaradi obljube možu, da bo skrbela za njegovega otroka, obtožila lastnega sina v prid prvorojenemu sinu moža, ki ga je imel z drugo ženo, da bi pastorka obvarovala obtožbe umora lastnega očeta. Vse te zgodbe odražajo splošno sprejete norme moralnih načel, ki so se spodobile za moralne, pametne in predvsem lojalne ženske, pa naj bo v odnosu do moža ali vladarja na dvoru.

Številni primeri narativnih ilustracij $\mathrm{z}$ moralno-didaktično konotacijo iz časa dinastije Han nakazujejo, da so bile tovrstne upodobitve splošno razširjene in uveljavljene že v tem zgodnjem obdobju konsolidacije kitajske cesarske moči. Po padcu dinastije Han še posebej z vdorom novih budističnih idej ter ponovno oživitvijo nekaterih lokalnih in tradicionalnih miselnosti so $\mathrm{v}$ narativnih ilustracijah opazne spremembe, ki jih lahko zaznamo tako $\mathrm{v}$ konceptualnem pristopu in kompoziciji kot tudi formatu. Kot ugotavlja Murray $(2007,49)$, so se iz prvotnega bolj ali manj religioznega konteksta razširile tudi v bolj posvetne upodobitve in prakse. Pri tem igra vodilno vlogo nova oblika prikazovanja v obliki zvitkov, ki so ponujali odlično strukturno ozadje za vizualno upodabljanje dogodkov v logično soslednem

3 Biografije žensk so razporejene v posamezna poglavja, ki so bila urejena glede na specifične kreposti moralnih žensk, kot npr. matere s pravilnim vedenjem, krepostne in pametne ženske, čednostne in nedolžne ženske, ubogljive ženske itd. Zadnje poglavje je vsebovalo tudi biografije hudobnih in izprijenih žensk. 
zaporedju. Eden izmed zgodnjih primerov predstavlja znan zvitek z naslovom Nüshi zhen tu 女史筬圖 (Opomin dvornim učiteljicam), ki ga tradicionalno pripisujemo očetu figuralnega slikarstva Gu Kaizhiju 顧愷之 (ok. 345-ok. 406). ${ }^{4}$ Slika v seriji devetih prizorov ${ }^{5}$ ilustrira pesem $\mathrm{z}$ istim naslovom, ki jo je spesnil dvorjan Zhang Hua 張華 (262-300) iz dinastije Zahodni Jin (265-316). Pesem, ki je bila spesnjena kot prikrito sporočilo razvpiti, pokvarjeni in brezobzirni cesarici Jia 賈後 (257-300) - ta je s svojim nemoralnim vedenjem ne le ogrožala cesarja, temveč tudi mir in stabilnost v celotni družbi -, je podajala primerno vedenje, ki naj bi mu sledile vse dvorne dame. Kot v prejšnjem primeru so tudi te zgodbe povzete po konfucijanskem kanonu za žensko obnašanje Lienü zhuan, kar odraža, da so tovrstni historični primeri postali že standardno razširjen način moralnega izobraževanja neizobraženih žensk. $\mathrm{V}$ prvem prizoru iz verzije Britanskega muzeja se pogumna gospa Feng 馮 sooči s podivjanim medvedom, da bi zaščitila cesarja, $\mathrm{v}$ drugem prizoru istega zvitka pa žena cesarja Chenga 成帝 (51-7 pr. n. št.) iz dinastije Vzhodni Han zavrne vožnjo s svojim možem in raje pešači za nosilnico, da ga ne bi motila pri opravljanju državnih poslov. $\mathrm{V}$ prizoru iz toalete, ki sledi v nadaljevanju, so dvorne dame podučene o pomembnosti kultiviranja notranjih kvalitet in ne le o obsesivnem lepotičenju ter zunanji negi.
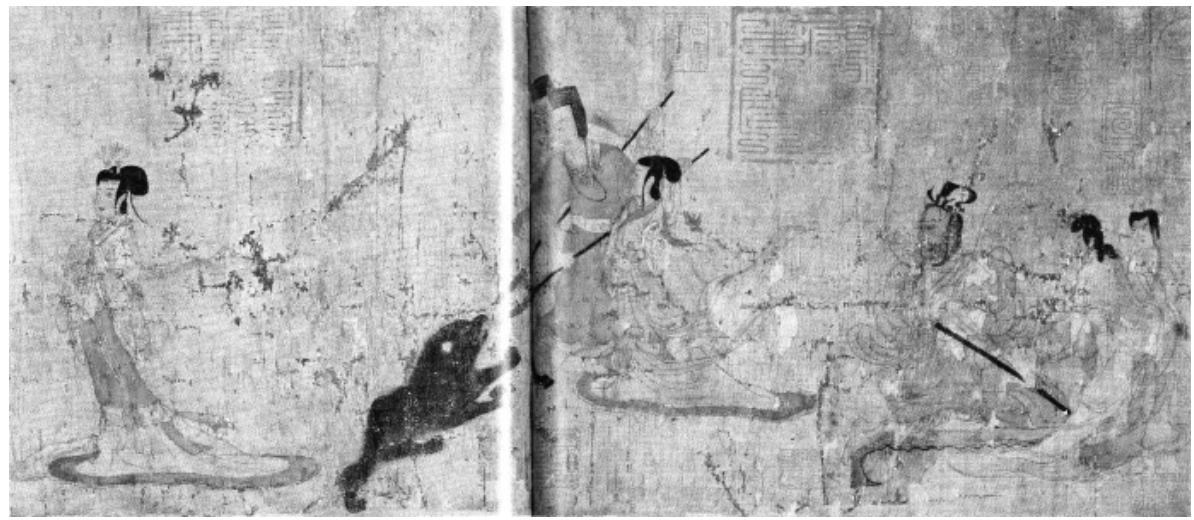

Slika 2: Prip. Gu Kaizhiju: Nüshi zhen tu. Gospa Feng z medvedom. Britanski muzej (vir: Stuart, 2014, 34-35).

V kasnejših obdobjih se tovrstno upodabljanje razvije v specifičen način ilustracij v obliki zvitkov, ki odražajo moralno in zgodovinsko resnico. To je še posebej vidno v času dinastije Tang, ko so vladarji formalizirali vzorce zaslužnih javnih uslužbencev in vojaških generalov ter jih pokroviteljsko povzdigovali ali nagrajevali za njihova

4 Danes prevladuje splošno mnenje, da je slika nastala med 5. in 6. stoletjem (Stuart, 2014, 11).

$5 \quad$ Na verziji slike, ki se nahaja v Britanskem muzeju, je prikazanih devet prizorov, medtem ko je na kopiji iz 12. stoletja, ki jo hranijo v Palačnem muzeju v Pekingu, prikazanih 12 prizorov. 
zaslužna moralna dejanja. Da je narativno slikarstvo v tem času postalo eno izmed najosnovnejših orodij za moralno kultivacijo posameznikov, kaže tudi uvodna izjava znanega umetnostnega teoretika, učenjaka in kaligrafa Zhang Yanyuana 張彥遠 (ok. 815-ok. 877), ki jo je zapisal v slavnem umetnostnozgodovinskem delu z naslovom Lidai minghua ji 歷代名畫記 (Zapisi o slavnih slikah preteklih dinastij): »Slikarstvo je zaslovelo po svojem civiliziranem vplivu in podpori človeškim odnosom « (Zhang, 1963, 1).

Moralno-didaktične konotacije v slikarstvu, ki so obsegale tudi številne ilustracije Konfucija in njegovih učencev, so postale še posebej razširjene in popularne v zadnjem stoletju dinastije Ming 明 (1368-1644), in sicer ne le v uradnem dvornem okolju, temveč tudi med navadnim prebivalstvom. Privrženci Wang Yangmingove 王陽明 filozofije, katere ključni pojem je zavest kot bistvo in osnova vsega bivanja in je lahko bodisi individualno človeška bodisi kozmična (Rošker, 2010, 202), so promovirali svoja prepričanja $\mathrm{v}$ prirojeno oziroma notranjo moralno naravo in s tem $\mathrm{v}$ kultivacijo tudi običajnih ljudi. $\mathrm{V}$ ta namen so podpirali izdajanje ilustracij s poučno noto, ki je bila namenjena širšemu krogu prebivalstva, hkrati pa so nekatere didaktične ilustracije na dvoru s pomočjo lesoreznih tehnik prešle v širši obtok umetniškega trga.

Tudi mandžurski cesarji dinastije Qing so sledili tem vzorom in s pomočjo vizualnega medija ter $s$ tem upodabljanja ritualnih, dokumentarnih in drugih pomembnih dogodkov utrjevali svojo moč in avtoriteto nad hanskim delom prebivalstva ter se predstavljali kot najidealnejši vzori modela konfucijanskega vladarja.

\section{Narava in koncept »konfucijanskega idealnega vladarja«}

Koncept xiao, ki se večkrat prevaja kot spoštovanje oziroma poslušnost v odnosu do nadrejenega, je v času dinastije Han postal osnovno vladarjevo vodilo za nadzor nad državo in njenimi prebivalci. Superiornost očeta in s tem vladarja tako izhaja iz koncepta xiao, ki je imel velik vpliv na politiko, ideologijo, miselnost, naravo vladarstva in ne nazadnje na vsakdanje življenje $\mathrm{v}$ času dinastije Han. Na pomembnost tega koncepta kaže tudi dejstvo, da so vsi cesarji dinastije Han po smrti dobili posthumni naziv s predpono xiao (Wu, 1989, 181). Xiao je tako postal osnova vseh vrlin in celotne civilizacije, vodilo vladarja pa vladanje na osnovi koncepta xiao. Pri tem gre namreč za recipročni odnos. Tudi nadrejeni ima določene dolžnosti in moralne obveznosti do svojih podrejenih. Konfucijanski vladar mora biti do svojih podanikov odgovoren, skrben in vzoren, sicer mu nebo ne bo podelilo nebeškega mandata oziroma mu ga bo odvzelo. Avtor Xiaojinga 孝經, osrednjega teksta konfucijanske morale, ki podaja 
glavna načela, ki nadzirajo odnose $\mathrm{v}$ idealni konfucijanski družbeni hierarhiji, $\mathrm{z}$ naslednjimi besedami definira xiao nebeškega sina - cesarja:

子曰：「愛親者, 不敢惡於人; 敬親者, 不敢慢於人。愛敬盡於 事親，而德教加於百姓，刑於四海. 蓋天子之孝也」。(Xiaojing, 2. poglavje).

Mojster pravi: »Tisti, ki ljubi starše, si ne bo upal biti osovražen s strani drugih ljudi; tisti, ki spoštuje starše, si ne bo upal biti obsojen prezirljivosti s strani drugih ljudi. Ko se ljubezen in spoštovanje [nebeškega sina] izražata v najglobljem smislu v odnosu do svojih staršev, lekcije moralnosti dosežejo vse ljudi in postanejo vzor vsem znotraj štirih morij. To je xiao nebeškega sina.«

To seveda nikakor ni bil izum dinastije Han, temveč predstavlja osrednji pojem in vrlino, ki jo definira že Konfucij. Ta je bil "prepričan o obstoju vseobsežnih zakonitosti, ki urejajo kozmos in jih je mogoče povzeti v konceptu neba (tian) kot najvišjega izraza naravne Urejenosti« (Rošker, 2010, 52). Tako vladar kot ljudstvo morata v svojem ravnanju slediti načelom kozmičnih zakonitosti, kar nadalje vodi $\mathrm{v}$ stanje naravne harmonije in miru. To idejo še podrobneje obdela Dong Zhongshu, saj naj bi obstoj tesne numerološke, anatomske, fiziološke in psihološke povezave med nebom in človekom namigoval na superioren položaj človeka, ki ga ločuje od ostalih stvari in ga postavlja $\mathrm{v}$ triado $\mathrm{z}$ nebom in zemljo (prim. Henderson, 1984, 4). Pri tem Dong Zhongshu vladarja definira kot edinega predstavnika na zemlji, ki je s svojim obnašanjem sposoben doseči resonanco oziroma harmonijo med nebom in človekom. V skladu s tem tudi podrobno interpretira pismenko za kralja wang 王. Po mnenju Dong Zhongshuja tri vzporedne vodoravne poteze simbolizirajo nebo-človekazemljo, navpična poteza pa predstavlja vladarja, katerega naloga je povezovanje vseh treh domen in vzpostavljanje komunikacije med njimi (Chunqiu fanlu, 44. poglavje, 328-333). Nebo tako pridobi status edinega legitimnega predstavnika vladanja, saj ga označi za aktivnega agenta, ki povzroča vsa dejanja v univerzumu. Postane najvišja moralna avtoriteta, ki se ji mora podrediti tudi sam vladar, saj nebeška znamenja $\mathrm{v}$ podobi najrazličnejših astronomskih pojavov vladarja opozarjajo na obvezo do moralno-etičnega in odgovornega vladanja. V nasprotnem primeru lahko enostavno izgubi pravico do vladanja in s tem nebeški mandat (prim. Vampelj Suhadolnik, 2009, 57-58).

Dong Zhongshu je bil izredno spreten politik in filozof, ki ne samo, da je vladarja postavil za najvišjega moralnega predstavnika med ljudmi, temveč ga je spretno podredil moralni avtoriteti neba in s tem konfucijanskim uradnikom. Ti so bili namreč edini pristojni, ki so lahko nebeško govorico tolmačili v cesarju razumljiv jezik, pri tem pa so nemalokrat sledili lastnim političnim ambicijam. V oblikovanju 
t. i. moralne kozmologije, ${ }^{6}$ ki je zagovarjala način vladanja na osnovi moralnih vrlin, izobraževanj in obredov, je opazno sistematično izločanje vojaške nadvlade, nasilja in moči pri prenosu oblasti. Vodilno vlogo $\mathrm{v}$ tej preobrazbi sta odigrala že oče in sin Liu Xiang 劉向 (79-8 pr. n. št.) in Liu Xin 劉歆 (ok. 46 pr. n. št.-23 n. št.), ki sta kot osnovo za dinastični prenos predlagala zamenjavo premagovalnega kroga petih faz (wuxing 五行) s krogom medsebojnega ustvarjanja in vzporedno s tem uporabo novega dinastičnega simbola ognja. S tem sta premagovanje in vojaško silo nadomestila $\mathrm{z}$ rojstvom in moralno vzgojo, dokončno preobrazbo in odstranitev vojaške moči pri prenosu oblasti pa je nadalje izpeljal Dong Zhongshu. Zagovarjal je, da je dao 道 neba edini legitimni način vlade, kroženje petih xingov pa pri tem služi le kot potrditev nebeške volje (prim. Vampelj Suhadolnik, 2006). Nebo je tako v neposrednem medsebojnem odnosu s človeškim svetom, ki vladarju dodeli nebeški mandat in pravico do vladanja vsemu pod nebom. Vladar lahko ukazuje ministrom, tako kot lahko očetje ukazujejo svojim otrokom, možje ženam in tako naprej vse do dna družbene hierarhije. Pri tem ključno vlogo igra ravno odnos med vladarjem in nebom, ki s pomočjo posebnih znamenj komunicira $\mathrm{z}$ vladarjem in utrjuje prvi člen v verigi hierarhičnih družbenih odnosov.

Da bi prikazovali upravičenost do nebeškega mandata in s tem utrjevali politično legitimacijo in kulturno avtoriteto ter promovirali dobrobit lastne vlade, so velikokrat posegli po vizualnem mediju narativnih ilustracij. Te so v svoji osnovni formi zvitkov postale idealna podlaga in s tem orodje za utrjevanje lastne podobe kot idealnega konfucijanskega vladarja, ki pri svojem vladanju uporablja vse moralno-družbene kodekse. V nadaljevanju bomo na primeru dveh vladarjev prikazali legitimacijo cesarske vlade in politične moči s pomočjo slikovne propagande.

\section{Slikovna propaganda cesarja Taizonga 太宗 iz dinastije Tang}

Konfucijanska politična filozofija je jasno definirala odnose med cesarjem in ministri $\mathrm{v}$ okviru recipročnih obveznosti. Cesar se je $\mathrm{v}$ tem sistemu obračal $\mathrm{k}$ svetovalcem in drugim zaslužnim ministrom, njihova dolžnost pa je bila dajanje napotkov in korekcije vladarjevega obnašanja. Tako so bile poučne ilustracije $s$ konkretnim namenom svarila ali opomina pravzaprav relevantne za obe strani. Vladar je lahko naročil izdelavo poučnih ilustracij, ki bi ga opominjale na moralno vladanje ter na upoštevanje pametnih nasvetov svojih podrejenih ministrov.

6 Aihe Wang z analizo tekstualne strukture teksta Wuxing zhi 五行志 (Razprava o wuxingu), ki je zajet v delu Hanshu, sistematično prikaže moraliziranje kozmologije wuxing (premik iz premagovalnega kroga v ustvarjalni krog) kot osnovo za transformacijo koncepta cesarske suverenosti v prvih dveh stoletjih cesarske dobe (Wang, 2000, 129-172). 
Ne glede na iskrenost ozadja tovrstnih cesarjevih naročil so te slike prispevale $\mathrm{k}$ boljšemu javnemu videzu ter odražale cesarjevo zavezo k idealom konfucijanske suverenosti.

Tega se je jasno zavedal tudi prvi cesar dinastije Tang, Taizong 太宗 (589649), še toliko bolj, ker je po več stoletjih politične razdrobljenosti in turbulentnih časov učinkovito izpeljal ponovno združitev cesarstva ter na temeljih pretekle in kratkotrajne dinastije Sui 隨 (581-618) vzpostavil trdno in močno državno strukturo, ki jo zgodovinarji večkrat označujejo kot »zlato dobo« kitajske zgodovine in civilizacije. Hkrati s priznavanjem budističnih in daoističnih idej je cesarski dvor utrdil tudi konfucijansko ideologijo ter $\mathrm{z}$ uporabo najrazličnejših medijev reproduciral ortodoksno učenje in vizualno umetnost. $V$ ta namen je cesar na dvoru zaposloval tudi umetnike in slikarje, pri čemer je osrednjo vlogo odigral Yan Liben 閻立本 (ok. 600673). Yan Liben je bil sicer minister po nazivu, vendar je bila njegova naloga izključno vezana na upodabljanje pomembnih dvornih dogodkov in političnih osebnosti po cesarjevem naročilu, njegovo slikarstvo pa je tako postalo sredstvo za utrjevanje politične oblasti in cesarske legitimnosti.

Cesar Taizong se je že $\mathrm{v}$ začetnem stadiju vladanja zavedal pomembnosti prikazovanja portretov zglednih mož, pri čemer se je zgledoval po predhodnikih iz časa dinastije Han. Leta 626 je Yan Libenu naročil poslikavo 18 zaslužnih učenjakov skupaj z napisi, ki jih je napisal neki drug učenjak (Wu, 1997, 60; Murray, 2007, 52). Leta 643 je slikar nadalje prejel naročilo za drugo serijo tovrstnih portretov, tokrat 24 izrednih generalov in civilnih uradnikov, ki jih je v skladu s starodavno tradicijo še iz časa dinastije Han upodobil na stene »Paviljona Lingyan«. Poleg tega je cesar menil, da primeri vzornih starodavnih vladarjev nudijo vse, kar vladar potrebuje za stabilno in modro vladanje (Murray, 2007, 52). Yan Liben je tako na zvitku upodobil portrete 13 preteklih vladarjev od časa dinastije Han do dinastije Sui. Zvitek, znan pod imenom Li dai diwang tu 歷代帝王圖 (Slike cesarjev preteklih dinastij), ki ga hrani bostonski muzej umetnosti, je klasičen primer slikarjevega lastnega dela in uradne tangovske politike do slikovne dokumentacije političnih in drugih družbenih dogodkov. 


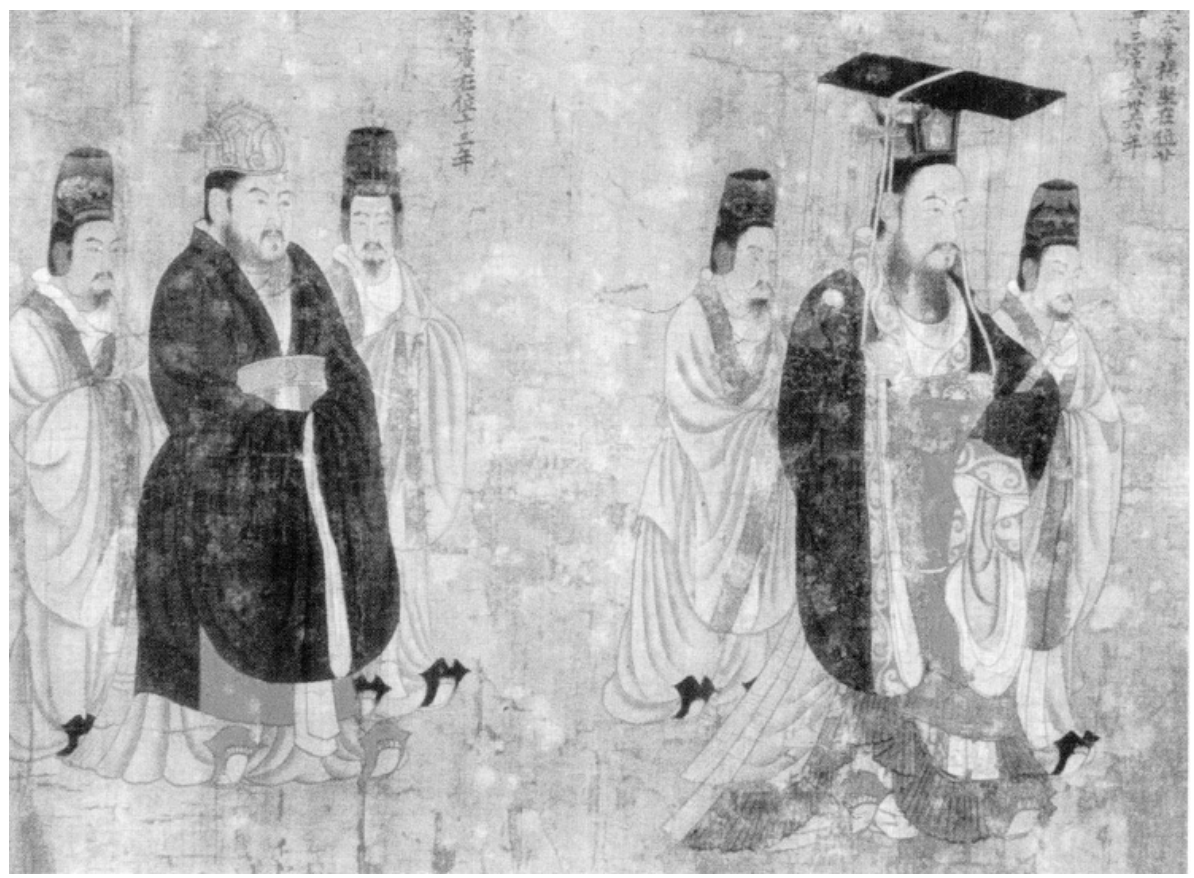

Slika 3: Prip. Yan Libenu: Lidai diwang tu. Cesar Wen in Yang iz dinastije Sui.

7. stoletje. Muzej umetnosti v Bostonu (vir: Murray, 2007, slika 12).

Zvitek prikazuje 13 individualno upodobljenih cesarjev, pri čemer je vladar vedno prikazan $\mathrm{v}$ tričetrtinskem profilu, $\mathrm{v}$ ozadju pa ga spremljata običajno pomanjšana spremljevalca. Napisi nadalje identificirajo upodobitev posameznih vladarjev, pri čemer se je slikar osredotočil tudi na notranji značaj in posamezne obrazne izraze. Z njihovo pomočjo je namreč razkril njihove politične zasluge in dejanja, tako nam ti portreti nazorno prikazujejo, kakšen odnos je tangovska uradna politika imela do posamičnih preteklih vladarjev. Kot omenja Murray $(2007,51)$, ukazovalen izraz na obrazu cesarja Wuja 武帝 (543-578) iz dinastije Severni Zhou 北周 (557-581) nakazuje na močnega vladarja, medtem ko usmiljen in obžalujoč izraz na obrazu zadnjega vladarja dinastije Chen 陳朝 (557-589) nakazuje na nekoga, ki bo ravnokar izgubil krono. Razlikovanje $\mathrm{v}$ različnem dojemanju posameznih vladarjev je opazno tudi v (ne)impozantni drži in cesarskih slovesnih oblačilih, ki so pri nekaterih luksuzno opremljena, pri drugih pa skromnejša.

Posamični portreti nazorno izražajo politična sporočila, celoten zvitek s prikazom 13 preteklih vladarjev pa zgodovino preteklih dinastij. Ta sporočila so cesarja dinastije Tang opozarjala na lastno moralno in politično obnašanje. Še posebej pomembna so bila kot poučen pripomoček bodočega vladarja, saj so mu čeravno komaj zaznavne 
vizualne razlike pri posameznih vladarjih služile kot model, katerim vladarjem slediti in katerim se izogibati.

Poleg portretiranja posameznih zaslužnih mož je imel cesarjev uradni slikar nalogo dokumentirati posamezne politične in družbene dogodke, s katerimi so proslavili in promovirali posamezne vladarjeve dosežke. Slika z naslovom Nosilnica (Bunian tu 步毣圖), ki jo hrani Palačni muzej v Pekingu, ${ }^{7}$ se nanaša na konkreten zgodovinski dogodek. Prikazuje cesarja Taizonga na nosilnici, ki pozdravlja in sprejema tibetanskega odposlanca - ministra Ludongzana, ki je leta 641 prišel v prestolnico Changan 長安, da bi kitajsko princeso Wencheng 文成 pospremil na Tibet, kjer se bo poročila s tibetanskim vladarjem. Slika tako predstavlja zapis o povezavi dveh narodnosti s poroko, gotovo izredno pomembnem dogodku tedanjega časa, ki je ugodno vplival na razvoj medsebojnih političnih odnosov.

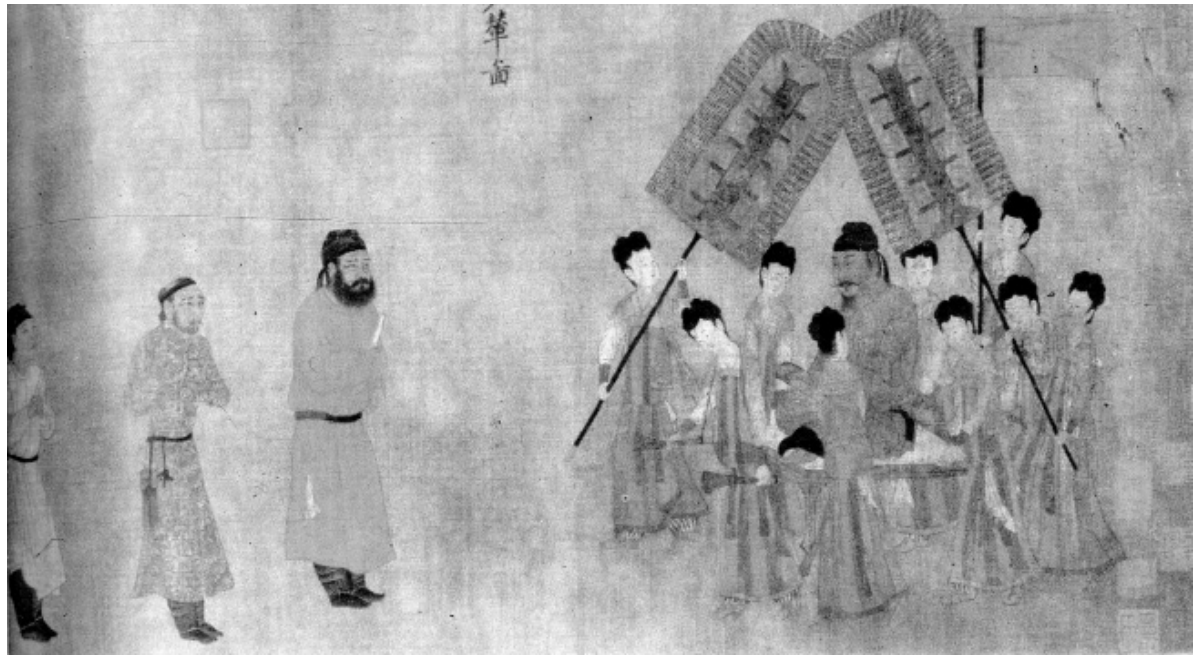

Slika 4: Prip. Yan Libenu: Bunian tu. Verjetno kopija iz dinastije Song.

Palačni muzej v Pekingu (vir: Wu, 1997, 61).

Vizualni jezik, ki je precej jedrnat, se osredotoča zgolj na dve skupini posameznikov, pri čemer še posebej izpostavlja odnos med dvema glavnima figurama - cesarjem in tibetanskim odposlancem -, ki predstavljata politična predstavnika Kitajske in Tibeta. Na desni strani je prikazan cesar v pokončno sedeči drži na nosilnici, ki jo nosi šest mladih dvorjank. Nosilnico spremljajo še tri dodatne dvorjanke $\mathrm{z}$ dvema ogromnima pahljačama in baldahinom, ki poudari cesarjevo pomembnost. Na levi strani je na sredini upodobljen tibetanski odposlanec, ki s sklenjenimi rokami pred prsmi in rahlo sklonjeno glavo upira pogled proti cesarju. Velikost posameznih oseb, izrazi na obrazu in njihovo vedenje

7 Najverjetneje gre za kasnejšo kopijo iz 12. stoletja (Wu, 1997, 60). 
ustrezajo statusu, ki jim pripada. Iz cesarjevega obraza je mogoče zaznati modrost in dostojanstvo, medtem ko so odposlanec in uradniki na drugi strani prikazani resno in spoštljivo. Cesar in tibetanski odposlanec tako dominirata na vsaki strani, njun način upodobitve, različni velikosti, položaj in obrazna mimika pa poudarjajo Taizongovo politično superiornost.

Slika tako ni zgolj poskus nevtralne slikovne zabeležke, temveč ideološki odraz odnosa cesarstva Tang do ljudstev, ki so živela ob njegovih mejah. Cesar Taizong ni bil le odličen politični in vojaški strateg, temveč je s svojo politiko odprtosti razširil stike s sosednjimi deželami. Mesto Chang’an je v času njegove vladavine postalo prestolnica $\mathrm{z}$ ambasadami in predstavništvi iz skoraj vseh azijskih držav. Tu so bivali številni predstavniki srednjeazijskih ljudstev, prihajali pa so celo poslanci iz Bizanca in pripadniki tujih verstev (judje, manihejci, nestorijanci itd.) (Saje, 2009, 110). Cesar je bil velik svetovljan in podpornik umetnosti, tako je glavno mesto kmalu postalo središče številnih kulturnih dogodkov, na dvor pa so prihajali številni umetniki iz drugih dežel. Ta politika se je povsem skladala $z$ načeli konfucijanske umetnosti vodenja države, po kateri naj bi dobrohoten vladar privabil tuja ljudstva $z$ vseh štirih koncev sveta ter jih s svojo višjo kulturno civilizacijo v središču pritegnil k prevzemanju superiornih kitajskih običajev in navad. Kasnejši pisci, ki so zapisovali posamezne izseke na zgoraj omenjen zvitek ali ga beležili v katalogih, so ves čas poudarjali tovrstno interakcijo in učinek superiorne kitajske kulture na tujce. V kolofonu iz leta 1307 je zapisano, da se je tibetanski vladar po poroki s princeso Wencheng siniziral ter začel nositi oblačila iz svile (Murray, 2007, 53). Tovrstne upodobitve tako slavijo moč kitajskega središča, ki mu je uspelo privabiti »barbare« iz periferije ter jih na prefinjen in eleganten način sinizirati, hkrati pa služijo prikazovanju cesarja kot vzornega konfucijanskega vladarja. To je bilo za cesarja Taizonga še toliko bolj ključnega pomena, saj je na poti do prestola ubil svoja dva brata ter prisilil očeta $\mathrm{k}$ odstopu. Da bi kljub temu pridobil slavo vzornega konfucijanskega vladarja, se je zatekel k preteklim vzorom ter številnim vizualnim projektom, ki so mu priznavali posamezne kvalitete konfucijanskega vladarja.

Tovrstna manipulacija in propaganda lastnih etičnih vrednot mu je očitno odlično uspela, saj so kasnejši zgodovinarji njegovo vladavino označili za zlato dobo cvetoče kulture, stabilnih gospodarskih in političnih razmer ter urejene diplomacije. Slike Yan Libena pa so $\mathrm{v}$ kasnejših interpretacijah splošno prikazane kot avtoritativna slikovna dokumentacija Taizongovih političnih in kulturnih dosežkov ter moralnega načina vladanja. 


\section{Slikovna propaganda cesarja Gaozonga 高宗 iz dinastije Song}

Naslednji primer, ki ga bomo obravnavali v sklopu pričujoče razprave, je deseti cesar dinastije Song 宋 (960-1279), znan pod imenom Gaozong 高宗, ki je hkrati ustanovitelj dinastije Južni Song 南宋 (1127-1279) s prestolnico v mestu Hangzhou 杭 州, kamor so se Kitajci zatekli pred uničujočo silo vojske Džurdžev, ki jih je napadala s severa. Čeravno je bilo kitajsko ozemlje precej okrnjeno ter so bili Kitajci prisiljeni v ponižujoč tributarni odnos z Džurdži, katerim so letno plačevali 500.000 enot svile (Saje, 2009, 147), je bil to čas ponovnega razcveta gospodarstva, trgovine in kulture. Najverjetneje pa so imeli cesarji prav zaradi zunanjih dejavnikov in $\mathrm{v}$ določenem obsegu podrejenosti tujim silam še večjo težnjo po utrjevanju lastne politične avtoritete, pri čemer so veliko vlogo odigrale ilustracije zgodb o konfucijanskem moralnem obnašanju, idealih upravljanja ter družbenem redu in harmoniji. Cesarji so $\mathrm{z}$ ilustracijami poskušali vplivati na uradnike, po drugi strani pa so sponzorirali tudi didaktične ilustracije za samoprevzgojo, ki naj bi povzdigovale njihovo predanost konfucijanskim načelom vladanja. Poleg omenjenih ilustracij imajo v tem času posebno vrednost ilustracije, namenjene mladim vladarjem oziroma prestolonaslednikom, saj naj bi na ta način najlažje vplivali na mladega cesarjevega sina, ki bi prevzel vse vrline konfucijanskih doktrin.

Didaktična vsebina narativnih ilustracij kot orodje za legitimacijo in konsolidacijo politične moči je bila še toliko bolj ključna za cesarja Gaozonga. V luči ponovne vzpostavitve oblasti na jugu Kitajske si je namreč moral utrditi položaj kot legitimni cesar dinastije Song, saj naj bi ta po zavzetju prestolnice Kaifeng 開封 s strani mandžurskega ljudstva Džurdžev očitno izgubila nebeški mandat. Poleg tega so Džurdži po kitajskem vzoru na severu ustanovili novo dinastijo, ki so jo poimenovali Jin 金 (1115-1234), ne nazadnje pa niti zadnji cesar dinastije Severni Song Qinzong 欽 宗 (1100-1161), ki so ga Džurdži zajeli, v ujetništvu ni abdiciral ter je še naprej obdržal uradno krono dinastije Song. S tega vidika je bilo Gaozongovo dejanje precej drzno, njegova moč in oblast pa vprašljiva.

Zavedajoč se šibke pozicije ter nasprotovanja številnih uradnikov in ministrov je sledil »politični« slikovni propagandi predhodnika Taizonga iz dinastije Tang ter ga pri tem še presegel. Takoj po vzpostavitvi nove oblasti na jugu Kitajske je spoznal ključno vlogo umetnosti pri vzpostavljanju nacionalne podobe. Oživitev dinastije je postala osrednja tematika njegove nove vlade, umetniki pa ključna komponenta državne propagande, zato je takoj po vzpostavitvi oblasti ponovno restavriral cesarsko akademijo slikarstva, kamor je privabil pomembne slikarje tedanjega časa. Da bi upravičil restavracijo dinastije Song pod imenom Južni Song in s tem ponovno 
potrditev s strani najvišje moralne avtoritete - neba, je od dvornih slikarjev zahteval upodobitev določenih historičnih zgodb in ilustracije specifičnih klasičnih literarnih tekstov, ki bi ugodno vplivale na sodobne okoliščine. Pri tem je s svojo kaligrafijo na slikah še dodatno utrjeval svoj položaj kultiviranega in omikanega cesarja, ki je cenil lastno kulturno dediščino.

Ena izmed najvidnejših slikovnih propagand, ki se je neposredno nanašala na njegovo restavracijo politične oblasti, je prikaz starodavne zgodbe iz obdobja Pomlad jeseni (770-476 pr. n. št.) o zmagoslavni vrnitvi vojvode Wen 文 v lastno državo Jin 晉 po državnem prevratu. Slika z naslovom Vojvoda Wen države Jin obnovi svojo državo (Jin Wengong fu guo tu 晉文公復國圖) je postala simbol za historični precedens, s katerim je Gaozong slavil politično restavracijo dinastije Song. Zgodba govori o vladarju države Jin po imenu Chonger 重耳 (697-628 pr. n. št.), ki je bil po državnem udaru izgnan iz države in primoran živeti v izgnanstvu celih 19 let. V tem času mu je uspelo vzpostaviti trdno zvezo $\mathrm{z}$ vladarji drugih držav, ki so mu omogočili zmagoslavni povratek $\mathrm{v}$ državo Jin. Slika $\mathrm{v}$ vodoravnem zvitku v prvih petih prizorih prikazuje bodočega vojvoda Wen pri novačenju zaveznikov in potovanju v sosednje države, kjer je večinoma deležen gostoljubnih gostij, v zadnjem delu pa je prikazan veliki povratek. Celotna procesija z vojvodo na vozu in bogatim spremstvom se od leve proti desni pomika proti vratom prestolnice države Jin, kaligrafski zapis pa potrjuje, da je sliko naročil Gaozong v zgodnjih letih svoje vlade, najverjetneje kmalu po poskusu državnega udara leta 1129, ki bi ga skoraj odnesel s prestola (Murray, 2007, 79).

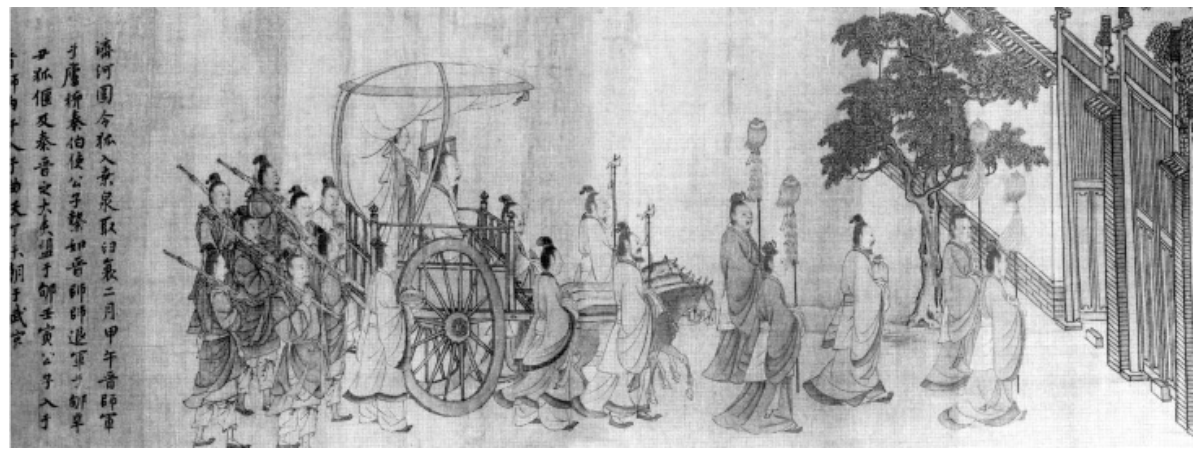

Slika 5: Prip. Song Gaozongu in Li Tangu: Jin Wengong fu guo tu. Detajl. 12. stoletje. Metropolitanski muzej umetnosti (vir: Murray, 2007, 79).

Zgovoren primer tovrstne propagande je mogoče zaznati tudi v vodoravnem zvitku z naslovom Osemnajst pesmi nomadske piščali (Hujia shiba pai 胡笳十八拍), ki ga je ravno tako naročil cesar Gaozong. Gre za ilustracije na pesmi o mladi pesnici in glasbenici Cai Yan 蔡琰 iz dinastije Vzhodni Han, ki jih je v dinastiji Tang spesnil Liu Shang (ok. 770). Cai Yan je bila v času vdorov Hunov na kitajsko ozemlje proti 
koncu dinastije Han zajeta in odpeljana v severne nomadske dežele, kjer je skoraj 12 let živela kot žena hunskega poglavarja in mu rodila dva sinova. Kasneje so se dogovorili za odkupnino ter jo odpeljali nazaj na Kitajsko, pri tem pa je za seboj pustila lastna otroka, kar je pustilo globoko rano v njenem srcu. ${ }^{8}$ Poet Liu Shang je zgodbo modificiral in dodal srečen konec $\mathrm{v}$ smislu tople dobrodošlice s strani njene družine, ki je hkrati nakazovala na moralno obvezo ujetnice do lastne kulture in civilizacije, ki naj bi odtehtala njeno žalost ob izgubi otrok. Predelana verzija tangovskega poeta je bila za Gaozonga idealna priložnost, s katero je lahko upravičil mirovno pogodbo z Džurdži in s tem osvoboditev lastne matere, ki so jo zajeli Džurdži ob vdoru v mesto Kaifeng. Hkrati pa je njena saga nakazovala na metaforično prispodobo za vse uradnike, ki so bili v izgnanstvu ter po izgubi politične moči njihovih nasprotnikov ponovno poklicani na dvor. Tovrstne upodobitve navad severnih »barbarov«, ki so se v slikarski terminologiji uveljavili kot žanr fanzu 番族 (»barbarska plemena«), so stepsko pastoralno življenje nadalje konstruirale kot nekaj, kar daleč odstopa od idiličnega in civiliziranega življenja Kitajcev na osrednji planjavi.

Medtem ko je zgoraj omenjena slika propagirala Gaozongovo za večino Kitajcev ponižujočo in neslavno mirovno pogodbo s tujimi barbarskimi ljudstvi, je vodoravni zvitek z naslovom Dobrodošlica cesarskemu vozu (Yingluan tu 迎鑾圖) še konkretneje promoviral vidni rezultat teh pogajanj (prim. Murray, 2007, 82-83). Slika prikazuje vrnitev Gaozongove matere iz ujetništva ter povratek trupel preminulega cesarja Huizonga 徽宗 (1082-1135) in dveh cesaric, ki so jih Džurdži ravno tako zajeli. Bolj kot natančno dokumentacijo slavne vrnitve je slika odražala simbolično reprezentacijo koncepta xiao ter s tem izražanja spoštovanja staršem in prednikom. $S$ tem je Gaozong poskušal mirovno pogodbo upravičiti kot dejanje, s katerim je pokazal lojalnost konfucijanskim vrlinam, ki bi ga ustoličile kot edinega legitimnega naslednika dinastije Song v kontekstu idealnega konfucijanskega vladarja, ki je prejel nebeški mandat.

Njegova težnja po priznavanju politične in kulturne avtoritete je narekovala izdelavo propagandnih ilustracij tudi v času njegove upokojitve, ko je že abdiciral v korist svojega naslednika Xiaozonga 孝宗 (1127-1194). Čeravno v tem času ni več potreboval politične podpore uradnikov in ministrov, ga je skrbela predvsem sodba kasnejših zgodovinarjev o njegovi historični vlogi in poziciji med vzornimi vladarji, po katerih se bodo zgledovali vsi kasnejši vladarji. V skladu s tem je omembe vredno predvsem literarno in slikovno delo Srečna znamenja za dinastično obnovo (Zhongxing ruiying tu 中興瑞應圖), ki zgovorno in shematično napoveduje Gaozongovo usodo rešitelja ogrožene dinastije in novopečenega ustanovitelja dinastije Južni Song, čeprav

8 Cai Yan je bila tudi sama pesnica, v njenih pesmih zaznamo osamljenost, žalost in željo po vrnitvi na Kitajsko, kjer ni imela nobenih sorodnikov več. 
je bil kot deveti sin cesarja Huizonga šele na repu lestvice za cesarsko nasledstvo. Pri tem je spretno uporabil Dong Zhongshujevo politično teorijo nebeškega mandata, ki v obliki najrazličnejših nenavadnih podob vizualno blagoslavlja novega vladarja in mu podeljuje nebeško nasledstvo. $S$ tem se mu je uspelo prikazati za edinega legitimnega naslednika dinastije Song in vseh ostalih »idealnih konfucijanskih vladarjev«, ki so prejeli podporo najvišje moralne avtoritete - neba.

\section{Mao Zedong kot poslednji konfucijanski vladar?}

MaoZedongov毛澤東(1893-1976) odnos do konfucijanskih idealovjepravzaprav precej ambivalenten. V zgodnjih letih je opazna določena simpatija do konfucianizma, ki kasneje, še posebej v kampanji proti Konfuciju v času kulturne revolucije, zapade v vrvež ostrih kritik. Mao se je zavedel, da mora za konsolidacijo svoje politične stranke vzpostaviti močno osrednjo oblast, zato se je v zgodnjih letih v svojih govorih zavezoval k spoštovanju konfucijanskih idealov in družbene hierarhije, v publikacijah pa večkrat poskušal svojo oblast in politiko legitimirati s pomočjo »konfucijanskega modela vladarja«. Leta 1938 je v govoru poudaril dediščino večtisočletne zgodovine in povzemanje posameznih vrednot vse od Konfucija do Sun Yat-sena (Sun Yixian 孫逸仙 1866-1925). »Naša naloga je študij naše zgodovinske dediščine, pri čemer jo moramo kritično evalvirati s pomočjo Marxove metode. Naš narod ima zgodovino več tisoč let, zgodovino s svojimi lastnimi pismenkami, ki je bogata zakladov ... našo zgodovino moramo povzeti vse od Konfucija do Sun Yat-sena ter prevzeti to dragoceno dediščino « (Mao, 1938). Pri tem mu sledijo njegovi privrženci. Liu Shaoqi 劉少奇 (1898-1969) - eden vodilnih protagonistov v kitajski politiki takoj za Mao Zedongom in Zhou Enlaijem 周恩來 (1898-1976) - se je v svojem priročnem učbeniku Kako postati dober komunist večkrat naslanjal prav na ideje Konfucija in njegovega naslednika Mencija (Gregor in Hsia Chang, 1979, 1077). »Vsak komunist, ki hoče postati dober ter politično zrel revolucionar«, ki bo veliko energije vložil v samokultivacijo, mora slediti Konfucijevemu vzoru (Liu Shaoqi v Zhang in dr., 1997, 195). Mao je ne nazadnje povzdigoval tudi Konfucijsko šolo v Konfucijevem rojstnem mestu Qufu 曲阜, še leta 1961 pa so komunisti organizirali konference o študiju Konfucija (Kongzi yanjiuhui 孔子研究會), saj naj bi bilo določene progresivne ideje še vedno mogoče najti v konfucijanski tradiciji.

Maove dileme o kompatibilnosti komunističnih ideologij in socializma s tradicionalnimi ideali konfucianizma pa so $\mathrm{v}$ kasnejših letih privedle do precej kritičnega vidika in napada na vse, kar je bilo povezano s starim »fevdalnim « sistemom, ki ga je simboliziral Konfucij. Maova antinomija med tradicijo in modernostjo se kaže v njegovih težnjah po t. i. kritični dediščini (Zhang, 1997, 195). Kot ugotavljata 
Zhang in Schwartz (1997, 195), je režim Mao Zedonga po eni strani želel negirati vse tradicionalne simbole, ki jih ni bilo mogoče vključiti v komunistično ideologijo, po drugi strani pa je prav v teh simbolih črpal moč. S pomočjo dekontekstualizacije jih je želel s pridom uporabiti pri konsolidaciji svojega političnega režima, pri tem pa je stare tradicionalne vrednote ovil le v nove simbolne povoje modernih teženj komunistične ideologije in socialističnih idej. Že leta 1940 je v Novi demokraciji zapisal: »vsi, ki zagovarjajo čaščenje Konfucija in študij konfucijanskih kanonov, se zavzemajo za stare etične kode in stare ideje ter nasprotujejo novi kulturi in novim idejam. Imperialistična kultura in semifevdalna kultura sta kot vdana brata, ki formirata reakcionarno kulturno zavezo proti novi kulturi Kitajske. To pa služi imperialistom in fevdalnim razredom, zato jo je treba odstraniti. Če tega ne storimo, ne moremo ustvariti nove kulture« (Mao, 1940).

S kulturno revolucijo (1966-1976) se je tako začela tudi velika kampanja proti Konfuciju, ki je simboliziral staro fevdalno družbo in vse, kar je bilo povezano $\mathrm{z}$ njo. Antikonfucijska kampanja je napadala vse vidike in vrednote konfucijanske družbe, ki so zajemali Konfucijev hvalospev zlati dobi starih vladarjev, moško usmerjeno hierarhično družbo, njegovo težnjo po samokultivaciji in intelektu, etične in po Mao Zedongovem mnenju neuniverzalne norme itd. Konfucija so spretno izrabili tudi za pregon nekaterih politično oporečnih voditeljev, kot je bil npr. Lin Biao 林彪 (19071971), obrambni minister ter nesojeni Mao Zedongov naslednik, ki se je obrnil proti njemu. V luči celotnega pregona je bilo veliko bolj smiselno, če so našli povezavo s Konfucijem, kar je bil dovolj močan argument za pregon. Lin Biao je bil tako kmalu obsojen in imenovan za novodobnega Konfucija, saj naj bi nad njegovo posteljo visela dva stiha iz znanih Konfucijevih Razprav (Lunyu 論語) (Mittler, 2008, 474).

Kljub temu, da so hoteli iz nove komunistične družbe odstraniti vse ideale konfucijanske družbe, je viden paradoks $\mathrm{v}$ ravno obratnem učinku. Ljudje so po uradnem naročilu nenadoma množično začeli brati Konfucija in konfucijanske klasike. Na ta način so ga pravzaprav na novo odkrili ter spoznavali stare obrede, norme in načela, pri tem pa jih kljub uradni državni propagandi interpretirali vsak $\mathrm{s}$ svojega vidika. »To gibanje je bilo huda kritika Konfucija, to je res, vendar pred tem gibanjem nihče od nas ni zares bral teh stvari, prav zaradi tega gibanja smo se začeli zavedati pomembnosti Konfucija ... takrat smo bili slepi, seveda, ampak nekako nisem verjel, da je bilo vse tako slabo pri njem« (Mittler, 2008, 475), je v intervjuju povedal umetnik.

Ironično je gotovo tudi dejstvo, da je celotno kampanjo proti Konfuciju pravzaprav navdihovala Konfucijeva lastna dediščina. Legitimnost vladarja sta zagotavljala moralno obnašanje vladarja in harmonija, ki mu jo je uspelo doseči v 
družbi in med podložniki, kajti šele na ta način sta mu bila zagotovljena nebeški mandat in možnost vladanja celotnemu kitajskemu ozemlju. Dinastična zgodovina je polna najrazličnejših zarot vladarjev, da bi prišli do laskavega naziva in se pokazali kot edini legitimni nasledniki svojih predhodnikov. Zarota, kot ugotavlja Fairbank (1992), je tako kontinuiteta cesarskega konfucianizma, pri čemer je kritika zgodovinskih primerov smiselna v družbi, v kateri je politični konsenz idealiziran. Ker seveda vsakršno nasprotovanje vodi v disharmonijo, ga je treba izraziti na prikrit način, ki upravičuje vladarjev prevzem oblasti. Pri tem je treba vse zarotnike in nasprotnike prav tako odstraniti na prikrit način, s pomočjo simbolnih podob, ki jih predstavljajo.

Čeprav je Mao zavračal in ostro kritiziral vse konfucijanske ideje, pa se je na ta način identificiral prav s Konfucijevim ugledom ter zgodovinsko dediščino. Kot številni pretekli »idealni konfucijanski vladarji« je pri prenosu oblasti posegel po podobnih orožjih in $\mathrm{v}$ modernih komunističnih ovojih pravzaprav izhajal iz konfucijanske tradicije. Vse te revolucionarne korake bi tako lahko interpretirali kot nekakšno transmutacijo konfucianizma, prepletenega z modernimi marksistično-leninističnimi komunističnimi ideali.

Za doseganje svojega cilja in konsolidacije lastne moči je tako Mao posegal po podobni vizualni propagandi, kot smo jo analizirali v prejšnjih poglavjih. Pri tem je šel še korak dlje, saj je skupaj s svojo četrto ženo Jiang Qing 江青 (1914-1991), ki je postala vodilna v kulturno-umetniškem sektorju, načrtno ustvarjal kult osebnosti, v katerem je mogoče zaznati že povsem božanske atribute. Brezhibna podoba Mao Zedonga je postala osrednja figura številnih poslikav, med katerimi je najbolj znana oljna slika z naslovom Predsednik Mao gre v Anyuan (Mao zhuxi qu Anyuan 毛主席去 安源). Slika upodablja odločnega mladega komunista v dolgem oblačilu z dežnikom $\mathrm{v}$ rokah, ki pogumno koraka čez hribe in doline, da bi vodil upor rudarjev v mestu Anyuan. Vsaka najmanjša poteza uteleša veliko miselnost Mao Zedonga in njegovega revolucionarnega duha. Star dežnik pod desno ramo demonstrira njegovo vztrajnost, trdo delo in potovanje $\mathrm{v}$ vsakršnih vremenskih razmerah, da bi dosegel svoje revolucionarne cilje. Slika pravzaprav predstavlja nekakšen protiudarec zgodnejšemu delu, ki je prikazovalo Liu Shaoqija kot vodjo rudarjev v mestu Anyuan. Ta je imel pri organizaciji delavskega gibanja v Anyuanu leta 1920 veliko pomembnejšo vlogo kot Mao. S tem je Mao svojega političnega nasprotnika povsem diskreditiral, oljna slika pa je postala ikona in najpomembnejša slika v času kulturne revolucije. ${ }^{9}$

9 Kot je ocenjeno, naj bi bila slika reproducirana 900-milijonkrat, plakat pa je bilo mogoče videti praktično na vseh javnih mestih, hišah, tovarnah in pisarnah. 


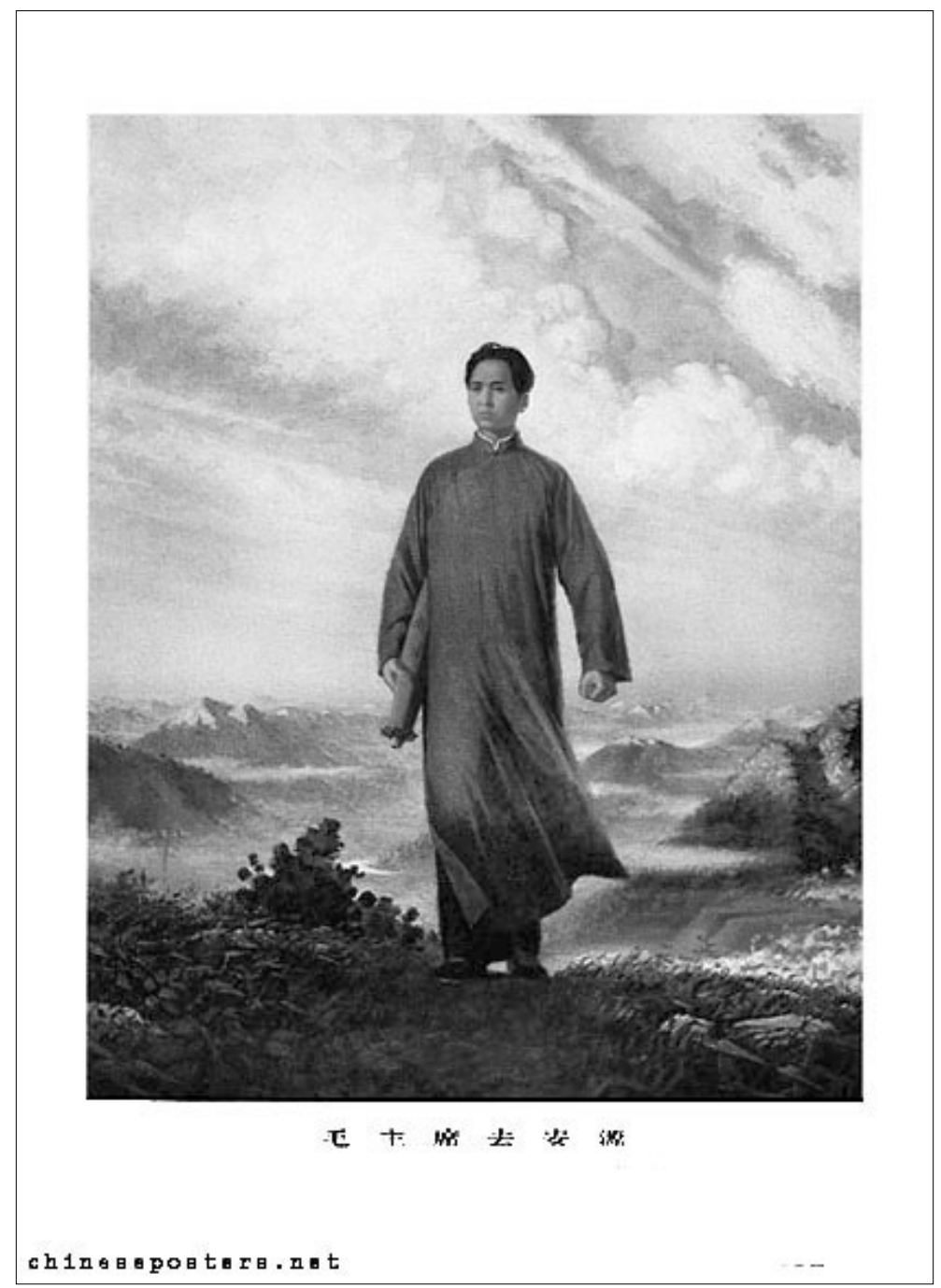

Slika 6: Liu Chunhua: Predsednik Mao gre v Anyuan, 106 x 76 cm, 1968 (vir: zbirka IISH, http://www.chineseposters.net/posters/e12-703.php).

$\mathrm{Na}$ propagandnih plakatih iz časa kulturne revolucije je Maova podoba dobila še močnejše konotacije velikega nebeškega vodje. Njegova smejoča se in brezhibna podoba se večkrat dviga nad množico ljudi, okrog glave pa se na vse strani širijo svetleči sončni žarki, ki osvetljujejo njegove misli in kot žarek upanja svetijo na Maove podanike. Tovrstne podobe že implicitno nakazujejo na nekakšne nadnaravne moči Mao Zedonga, ki se s tem identificira $z$ legendarnimi predniki, ki so nemočno in neomikano ljudstvo popeljali v svet kulturnih in družbenih civilizacijskih dosežkov. 


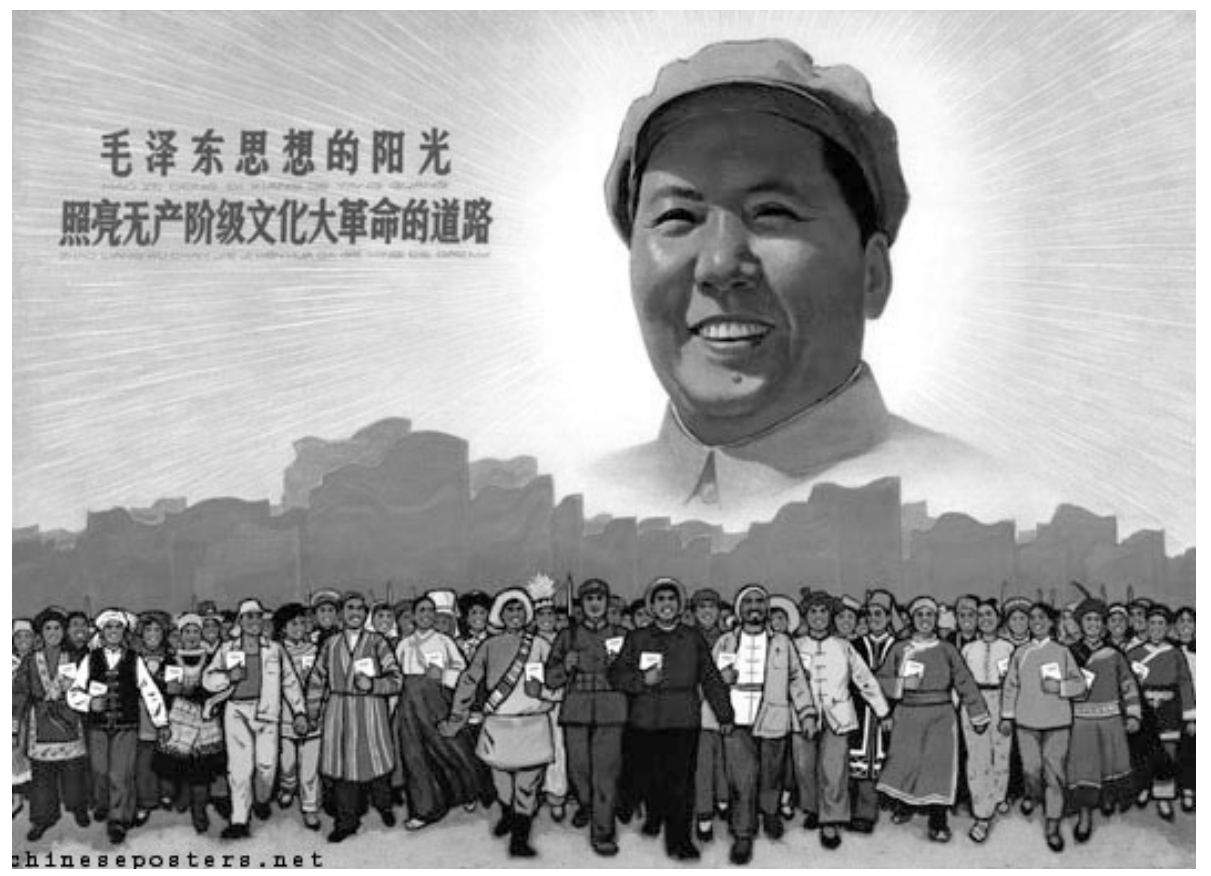

Slika 7: Sončni žarki Mao Zedongove misli osvetljujejo pot velike proletarske kulturne revolucije, propagandni plakat, velikost: 53,5 x 74 cm, 1966 (vir: Landsbergerjeva zbirka, http://www.chineseposters.net/posters/e13-644.php).

V skladu z uradno umetniško politiko in usmeritvijo je njegova podoba morala odsevati tri načela upodabljanja: rdeče (hong 紅), ožarjenost s svetlobo ( $g u a n g$ 光) in bleščeče (liang 亮). Nikakor pa snovalec plakatov ni smel uporabiti temnih odtenkov ali sive oziroma črne barve, saj je uporaba teh barv označevala vse kontrarevolucionarne težnje. Kot že omenjeno, je bila Maova glava v številnih primerih obdana s svetniškim sijem, ki je izžareval božansko svetlobo in razsvetljeval obraze prisotnih. V tem se je približal podobam številnih bud in bodhisatev, ki so z usmiljenim izrazom in mirom na obrazu tolažili verne podanike. Poleg tega so bili vsi detajli njegove podobe prepleteni z določenim simbolnim pomenom, ki jih je želel posredovati ljudstvu ter pridobiti njegovo politično podporo. Kot idealen vladar je na propagandnih plakatih prikazoval tudi odgovornost, lojalnost in navezanost na običajne ljudi, pa naj bo ob nadziranju posamičnih opravil na poljih in v tovarnah, rokovanju in klepetu s kmeti, plavanju in opravljanju povsem običajnih opravil. S tem je vzorno sledil recipročnemu odnosu, ki ga promovirajo konfucijanski ideali.

Propagandne plakate v slogu socialističnega realizma kot pomembne vizualne sporočilne govorice je spretno uporabljal ne le za konstrukcijo kulta osebnosti, 
temveč tudi za utrditev političnega režima in reform, ki jih je začel izvajati. S plakati so promovirali zemljiške reforme, kolektivizacijo, industrializacijo, elektrifikacijo, mehanizacijo podeželja, nove zakone in boj proti korupciji, stalna tema pa so postale tudi najrazličnejše kampanje, ki jih je sprožil Mao. Hkrati je s tovrstno govorico utrjeval svoj položaj, položaj komunistične stranke ter novoustanovljene države Ljudske republike Kitajske. Podobno kot Song Gaozong, ki je s historičnim prikazom ponovnega zavzetja prestolnice legitimiral svojo oblast kot edino legitimno nasledstvo dinastije Song, je tudi Mao z upodobitvijo ustanovitve Ljudske republike Kitajske novoustanovljeni vladi krepil politično avtoriteto.

Tako kot pretekli vladarji se je tudi Mao zavedal pomembne vloge, ki jo umetnost igra pri konsolidaciji državne moči. Že takoj od ustanovitve LRK oktobra 1949 je prevzel nadzor nad umetniškim sektorjem, izobraževanjem umetnikov ter ne nazadnje nad njihovim življenjem in delom. Z ustanovitvijo uradne Zveze kitajskih umetnikov (Zhong guo meishujia xiehui 中國美術家協會), ki je delovala pod okriljem ministrstva za kulturo, lahko povlečemo vzporednice s cesarsko akademijo umetnosti, ki so jo cesarji vzpostavili v času dinastije Song, da bi na svojem dvoru zbrali vse pomembne umetnike, ki bi delovali pod njihovim okriljem in prispevali k cesarjevi podobi idealnega konfucijanskega vladarja. Glavni namen Maove Zveze umetnikov je bilo ravno tako novačenje, izobraževanje in prevzgoja umetnikov, ki bodo lahko po svojih najboljših močeh služili LRK. Kot ugotavlja Sullivan $(1996,129)$, je bil namen zveze organizirati umetnike za nacionalno rekonstrukcijo, ustvarjati ideološko umetnost visoke kvalitete, formirati študij umetnostne teorije, temelječe na marksistično-leninističnih postavkah, ki jih je $\mathrm{v}$ Yan’anskem govoru izpostavil Mao Zedong, spodbujati širše množice delavcev, da prevzamejo aktivno vlogo $\mathrm{v}$ umetnosti, organizirati razstave, izdajati revije itd. Mao Zedong je hotel imeti nadzor nad celotnim programom kulturnih projektov. Ta je moral slediti načelom, ki jih je sam izpostavil v slavnem Yan'anskem govoru o literaturi in umetnosti (Zai Yan'an wenyi zuotanhui shang de jianghua 在延安文藝座談會上的講話) maja $1942 \mathrm{v}$ mestu Yan’an 延安 v provinci Shaanxi 陝西. V tem govoru je podrobno razložil svoj filozofski pogled na umetnost in kulturo, pri čemer je sledil marksistično-leninistični filozofiji, prepleteni z elementi tradicionalne kitajske družbene morale. Umetnost, namenjena predvsem delavskemu razredu, mora biti revolucionarna in množična. Kot taka mora kot podpora socializmu in komunizmu služiti izključno političnim interesom. Pri tem mu je vzor v zgodnjih letih predstavljal uradni slog slikarstva Sovjetske zveze - socialistični realizem, kjer je bila slika strukturirana kot naracija. Čeravno v tehniki oljnega slikarstva, ki so ga Kitajci prevzeli od zahodnih umetnikov, je tako formalni okvir socialističnega realizma bolj ali manj ustrezal tradicionalnim zvitkom z narativnim pridihom, kjer se je naslikana zgodba brala kot knjiga. 
Mao Zedong je postal utelešenje vseh najvišjih idealov in vzornik slehernemu posamezniku. Kot veliki učitelj, moder vodja in uspešen vojskovodja je prikrito izražal ideale tradicionalne konfucijanske kulture, pri tem pa je mogoče zaznati njegovo identifikacijo s konstruiranim modelom idealnega konfucijanskega vladarja, ki je pridobil nebeški mandat. $\mathrm{V}$ tem konstruktu gre še korak dlje, saj ne samo, da mu je nebo podelilo pravico do vladanja in ustvarjanja harmoničnega reda $\mathrm{v}$ novo formirani komunistični družbi, temveč se kar sam postavi na nebeški piedestal in prevzame določene »božanske značilnosti« neba.

Za zaključek naj omenim samo še stensko poslikavo v Veliki ljudski dvorani (Renmin dahui tang 人民大會堂), ki sama po sebi dovolj zgovorno priča $\mathrm{v}$ prid $\mathrm{t}$. i. konceptu »konfucijanskega vladarja«, ki so ga številni pretekli vladarji s pridom izkoriščali za legitimacijo politične avtoritete. Po vzoru preteklih vladarjev so namreč na steno nacionalnega hrama komunistične ideologije upodobili ogromno sliko, ${ }^{10}$ katere vsebina se je nanašala na Maovo pesem Oda snegu. Slika upodablja bogastvo in lepoto širnega kitajskega ozemlja, nad katerim se na desni strani prikazuje rdeče sonce. Rdeče sonce tako postane splošni vizualni simbol vzpona komunistične partije ter simbol naraščajočega Maovega kulta osebnosti. Sama namestitev na steno dvorane, pred katero običajno poteka skupinsko fotografiranje vseh politikov ter drugih pomembnih gostov - tudi tujih državnikov -, še dodatno prispeva k njeni namembnosti in utrjevanju politične hegemonije osrednjega cesarstva.

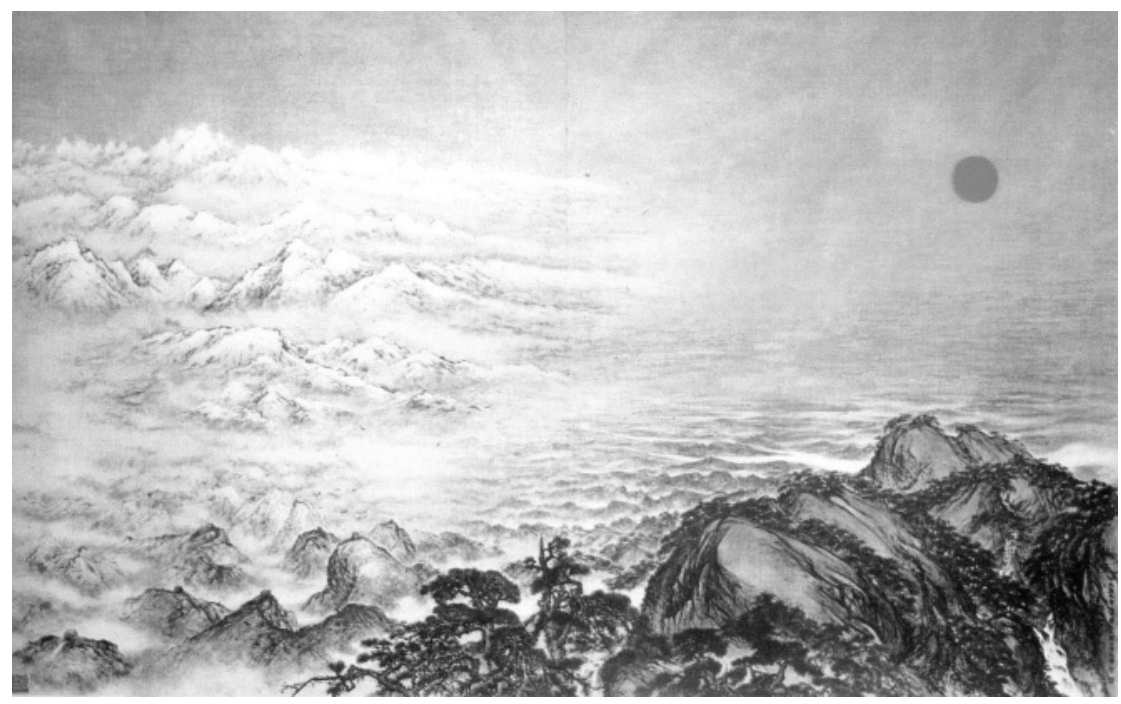

Slika 8: Fu Baoshi in Guan Shanyue: To je lepota naših gora. Stenska poslikava v Veliki ljudski dvorani, 5,5 x 9 m, 1959 (vir: Sullivan, 1996, slika 31). 


\section{Sklep}

V celotni kitajski zgodovini je vizualni medij kot sredstvo prepričevanja igral odločilno vlogo $\mathrm{v}$ legitimaciji političnih avtoritet posameznih vladarjev, ki so se z namenom, da bi prikazali pridobitev nebeškega mandata, poskušali prikazati kot idealni konfucijanski vladarji. To jim je večkrat uspevalo s pomočjo moralnodidaktičnih prijemov slikarskega medija v obliki narativnih ilustracij in upodabljanja najrazličnejših preteklih vzornih zgodb ter vojaških, političnih in kulturnih zaslug posameznih vladarjev, uradnikov, ministrov in generalov. $\mathrm{S}$ tem niso le »moralizirali« in navdihovali višjega sloja, temveč so s popularizacijo prodrli tudi med širše plasti prebivalstva. To je še posebej očitno od dinastije Ming naprej, saj so se tovrstni motivi začeli pojavljati v širšem umetniškem mediju, ki je zajemal tudi materiale, kot so lesorezni tiski ter porcelanaste in lakirane posode. Te stvaritve so bile običajno delo anonimnih obrtnikov, ki so zavzemali povsem drugačno pozicijo v kitajski vizualni kulturi, v kateri je vodilno vlogo igrala visoka in prestižna umetnost literarnih izobražencev.

Razprava v zadnjem poglavju je pokazala, da so narativne ilustracije - sicer v modernejši preobleki novih ideologij 20. stoletja - pomembno mesto v vizualni kulturi obdržale tudi v 20. stoletju, ki ga je zaznamovala nadvlada komunistične partije z Mao Zedongom na čelu. Ta je po vzoru preteklih vladarjev s pomočjo konstrukta »konfucijanskega idealnega vladarja « utrjeval lastno politično avtoriteto, pri tem pa je konfucijanski model spretno izluščil iz tradicionalnih okvirjev ter ga umestil v komunistično-socialistične ideale Marxove in Leninove teorije. Kljub temu, da je povsem zanikal in ostro kritiziral staro fevdalno konfucijansko družbo in vse, kar je bilo povezano s tem, med drugim tudi tradicionalno kitajsko slikarstvo, ki je zavračalo realistično upodabljanje in težilo k zajetju notranjega duha, je v primežu zahodnih tehnik in socialističnega realizma $\mathrm{v}$ obliki propagandnih plakatov poskušal doseči širši krog delavcev in kmetov. S prikazovanjem družbeno angažiranih tematik, političnih reform, futuristične podobe moderne in tehnološko razvite Kitajske si je utrjeval vodilni položaj, pri tem pa prikrito sledil preteklim konfucijanskim vzorom, ki jih je implicitno konstruiral v idejno ozadje vizualno umetniškega medija. Pri tem je šel še korak dlje in $\mathrm{v}$ konstrukcijo kulta osebnosti dodal pridih božanske esence, nekakšnega legendarnega vodje in posrednika znanja med nebom in zemljo. Le on je bil namreč tisti, ki je imel božansko avtoriteto posredovanja znanja - družbenega, političnega, kulturnega in tehnološkega -, s katerim bi revno, nevedno in podložno prebivalstvo popeljal v svet civilizacijskega napredka. Pri tem si ne moremo kaj, da ne bi povlekli vzporednice s konfucijansko politično teorijo, ki jo je že v času dinastije Han izoblikoval Dong Zhongshu. Vladarja je namreč postavil za najvišjega moralnega 
predstavnika na zemlji, ki je s svojim obnašanjem vplival na harmonične odnose v celotni družbeni hierarhiji ter na uravnoteženo kozmično delovanje. V tej luči bi Maov kult pravzaprav lahko označili zgolj za refleksijo starodavnih idejnih vrednot, ki jih je izredno spretno transformiral v moderne težnje novodobnih ideologij, prežetih $\mathrm{z}$ zahodnimi načeli.

\section{Literatura}

Dong, Z., Chunqiu fanlu yizheng 春秋繁露義證 (Niz biserov $v$ Spomladansko-jesenskih letopisih s tekstno kritiko pomenov), (ur. Su, Y., komp. Zhong, Z.), iz zbirke: Xin bian zhu zi jicheng 新編諸子集成 (Novo urejena zbirka vseh filozofskih del), Peking 2002.

Fairbank, J. K., China: A New History, Cambridge 1992.

Fairbank, W., The Offering Shrines of »Wu Liang Tz'u, Harvard Journal of Asiatic Studies, 6/1, 1941, str. 1-36.

Gregor, A. J. in Hsia Chang, M., Anti-Confucianism: Mao's Last Campaign, Asian Survey, 19/11, 1979, str. 1073-1092.

Henderson, B. J., The Development and Decline of Chinese Cosmology, New York 1984.

Mao Z., 1938, The Role of the Chinese Communist Party in the National War, v: Selected Works of Mao Tse-tung, 2, Peking 1965-1977, str. 209.

Mao Zedong, 1940, On New Democracy, Selected Works of Mao Tse-tung, 2. Peking 1965-1977, https://www.marxists.org/reference/archive/mao/selected-works/ volume-2/index.htm [17. 10. 2015].

Mittler, B., Popular Propaganda? Art and Culture in Revolutionary China, Proceedings of the American Philosophical Society, 152/4, 2008, str. 466-489.

Murray, J. K., Mirror of Morality: Chinese narrative illustration and Confucian Ideology, Honolulu 2007.

Rošker, S. J., Odnos kot jedro spoznanja. Kitajska filozofija od antičnih klasikov do modernega konfucijanstva, Ljubljana 2010.

Saje, M., Veličina tradicionalne Kitajske: zgodovina Kitajske od dinastije Qin do Song, Ljubljana 2009.

Sullivan, M., Art and Artists of Twentieth-Century China. Berkeley, Los Angeles, London 1996.

Stuart, J., The Admonitions Scroll, London 2014.

Vampelj Suhadolnik, N., Razvoj korelativne kozmologije yin-yang wuxing, Azijske in afriške študije, 10/1, 2006, str. 99-127. 
Vampelj Suhadolnik, N., Načelo korelativnosti v klasični kitajski kozmologiji, Dialogi, 45/9 2009, str. 54-74.

Wang, A., Cosmology and Political Culture in Early China, Cambridge 2000.

Wu, H., The Wu Liang Shrine: The Ideology of Early Chinese Pictorial Art, Stanford 1989.

Wu, H., The Origins of Chinese painting: Paleolithic Period to Tang Dynasty, v: Three Thousands Years of Chinese Painting (ur. Barnhart, R. M. in dr.), New Haven, London 1997, str. 15-85.

Xiaojing 孝經, Chinese text project, http://ctext.org/xiao-jing [15. 10. 2015].

Xie He 謝赫, Guhua pinlu 古畫品錄 (Zapisi o starodavnih slikarjih), v: Some Tong and pre Trang Texts on Chinese Painting (ur. Acker, R. B. W.), 1, Leiden 1954, str. $1-32$.

Zhang, T. in dr., Confucius and the Cultural Revolution: A Study in Collective Memory, International Journal of Politics, Culture and Society, 11/2, 1997, str. 189-212.

Zhang Yanyuan 張彥遠, Lidai minghua ji 歷代名畫記 (Zapisi o slavnih slikah preteklih dinastij), Šanghaj 1963. 
Nataša Vampeli Suhadolnik

\section{Mao Zedong kot poslednii konfucijanski vladar? Moralno-didaktični vidik »konfucijanske« umetnosti}

Ključne besede: konfucijanska umetnost, moralno-didaktični vidik, narativno slikarstvo, cesar Taizong, cesar Gaozong, Mao Zedong

Pričujoči članek obravnava problematiko moralno-didaktičnega vidika »konfucijanske umetnosti«, ki nastopa v obliki t. i. narativnega slikarstva. Z namenom legitimacije politične avtoritete so številni vladarji s pomočjo vizualnega medija promovirali konfucijanske družbene in politične vrednote, ki bi jih prikazali kot idealne konfucijanske vladarje. Na primeru dveh vladarjev - prvega cesarja dinastije Tang Taizonga (589-649) ter ustanovitelja dinastije Južni Song Gaozonga (1107-1187) - bomo poskušali prikazati koncept »konfucijanskega idealnega vladarja«, kot ga razkrivajo posamezni primeri narativnih ilustracij.

Izhajajoč iz teh primerov bomo $\mathrm{v}$ zadnjem delu članka poskušali interpretirati slikovno propagando velikega vodje komunistične Kitajske Mao Zedonga (18931976), ki je ravno tako s pomočjo didaktičnih ilustracij v obliki propagandnih plakatov širil moderne ideje komunistične ideologije. Pri tem je večkrat prikrito sledil modelu »konfucijanskega vladarja «, čeravno ga je ovil v simbolne ovoje modernih ideologij 20. stoletja. Ali bi torej lahko Mao Zedonga označili za poslednjega »konfucijanskega idealnega vladarja«, bo osrednje vprašanje zadnjega dela pričujočega članka. 


\section{Nataša Vampeli Suhadolnik}

\section{Mao Zedong as the Last Confucian Ruler? The Moral-Didactic Aspect of "Confucian" Art}

Keywords: Confucian art, moral-didactic aspect, narrative illustration, Taizong emperor, Gaozong emperor, Mao Zedong

The present article deals with the moral-didactic aspect of "Confucian" art, as seen primarily in the form of narrative illustration. In order to legitimize their authority, many rulers used visual media to promote or affirm Confucian social and political values, and thereby presented themselves as ideal Confucian rulers. The article analyses the use of narrative illustration by two exemplary historical figures - the first emperor of the Tang dynasty, Taizong (589-649) and the founder of the Southern Song dynasty, Gaozong (1107-1187) - in order to define the concept of the "Confucian ideal ruler".

Based on this concept, the article then analyses the pictorial propaganda of the great Chinese communist leader, Mao Zedong (1893-1976). Mao also used didactic illustrations, in the form of propaganda posters, to disseminate communist ideology. He implicitly followed the model of the "Confucian ruler", even if the figure was couched in the symbols of a $20^{\text {th }}$-century ideology. The article concludes by arguing that Mao Zedong can thus be considered the last "Confucian ideal ruler". 